Article

\title{
Hydroxyapatite Formation on Self-Assembling Peptides with Differing Secondary Structures and Their Selective Adsorption for Proteins
}

\author{
Suzuka Kojima $\bigotimes^{\circledR}$, Hitomi Nakamura, Sungho Lee, Fukue Nagata and Katsuya Kato * \\ National Institute of Advanced Industrial Science and Technology, 2266-98, Anagahora, Shimo-Shidami, \\ Moriyama-ku, Nagoya, Aichi 463-8560, Japan; suzuka-kojima@aist.go.jp (S.K.); hi.nakamura@aist.go.jp (H.N.); \\ sungho.lee@aist.go.jp (S.L.); f.nagata@aist.go.jp (F.N.) \\ * Correspondence: katsuya-kato@aist.go.jp; Tel.: +81-52-736-7551; Fax: +81-52-736-7405
}

Received: 19 July 2019; Accepted: 17 September 2019; Published: 19 September 2019

check for updates

\begin{abstract}
Self-assembling peptides have been employed as biotemplates for biomineralization, as the morphologies and sizes of the inorganic materials can be easily controlled. We synthesized two types of highly ordered self-assembling peptides with different secondary structures and investigated the effects of secondary structures on hydroxyapatite (HAp) biomineralization of peptide templates. All as-synthesized HAp-peptides have a selective protein adsorption capacity for basic protein (e.g., cytochrome c and lysozyme). Moreover, the selectivity was improved as peptide amounts increased. In particular, peptide-HAp templated on $\beta$-sheet peptides adsorbed more cytochrome c than peptide-HAp with $\alpha$-helix structures, due to the greater than 2-times carboxyl group density at their surfaces. It can be expected that self-assembled peptide-templated HAp may be used as carriers for protein immobilization in biosensing and bioseparation applications and as enzyme-stabilizing agents.
\end{abstract}

Keywords: solid-phase peptide synthesis; hydroxyapatite; peptide; secondary structure; selective protein adsorption; biotemplate

\section{Introduction}

As represented by bone, tooth, pearl, coral, shell, and crustacea, certain organisms have the ability to synthesize inorganic materials with refined structures and superior physical properties that are difficult to imitate. Such biomechanisms are designated as 'biomineralization', which is known as an environmentally-friendly synthesis process of inorganic materials under mild conditions. Synthetic methods of generating bioinspired materials and bioceramics have been reported by many researchers [1-3]. Liu et al. prepared calcium carbonate $\left(\mathrm{CaCO}_{3}\right)$-regulated silk fibroin and estimated the drug release of doxorubicin using its vaterite microspheres [4]. DNA-Cu $\left(\mathrm{PO}_{4}\right)_{2}$ hybrid nanoflowers were synthesized by Wu et al., and these materials are predicted to employ microRNA detection as captors [5]. He et al. described the synthesis of hematite mesocrystals with hierarchical structures via collagen templates [6]. Biominerals and bioinspired materials continue to be developed and are utilized within a variety of biosensing and biomedical applications.

Even in biomineralization, organic molecules play a crucial role in the formation of the crystalline nucleus and control of crystal polymorphism in vivo, as well as crystal growth and the shaping of the whole inorganic mineral. For example, peptides, which have unique well-ordered structures within their side chains, have been used as organic molecules to synthesize inorganic materials in a variety of methods [7-11]. Wada et al. controlled $\mathrm{CaCO}_{3}$ crystallization within hydrogels by mixing polylysine and polyaspartic acid via double-diffusion methods; furthermore, the influence of peptide in the 
formation of the composites was elucidated [12]. "End-tethered poly(L-lysine)" monolayer brushes have been employed on silica film mineralization as reported by Wu and colleagues [13]. In summary, small amounts of peptides can affect materials morphologies and surface potentials [14].

Recently, self-assembling peptide-templated inorganic materials have been developed to readily manipulate the functional groups and secondary structures in peptides [15-24]. Lu et al. designed $\beta$-folded glutamic acid (leucine-glutamic acid) ${ }_{9}\left(\mathrm{E}(\mathrm{LE})_{9}\right)$ peptides, with its peptides working as a key player in the formation of calcium oxalate nanosheets [25]. $\mathrm{Xu}$ and colleagues reported the synthesis of inorganic materials based on short peptide self-assembly designed as $I_{m} K_{n}$ (e.g., isoleucine-isoleucine-isoleucine-lysine, $\mathrm{I}_{3} \mathrm{~K}$ ), $\mathrm{I}_{\mathrm{m}} \mathrm{E}_{\mathrm{n}}$ (e.g., isoleucine-isoleucine-isoleucine-glutamic acid, $I_{3} E$ ), and $I_{m} R_{n}$ (e.g., isoleucine-isoleucine-isoleucine-isoleucine-arginine-arginine, $I_{4} R_{2}$ ) [26-29]. $\mathrm{Xu}$ et al. revealed that control of morphology and size of nanostructures were observed by using a self-assembling peptide template. In addition, our group previously showed that the morphologies of inorganic materials are controlled on a self-assembling peptide template [30-33] and elucidated that the secondary structures of peptides have a great impact on the resulting particles.

Hydroxyapatite $\left(\mathrm{Ca}_{10}\left(\mathrm{PO}_{4}\right)_{6}(\mathrm{OH})_{2}\right.$, termed $\left.\mathrm{HAp}\right)$ composes the primary inorganic contents of human tooth and bone and is a representative of biomineralization and bioinspired materials [34-40]. Hadagalli et al. established mineralization of porous HAp scaffolds, in which pores are obtained using organic pore formers, such as wax, wheat flour, or milk powder, and exhibit good cytocompatibility with osteoblasts in vitro [41]. Wei et al. synthesized biomineralized microspheres as follows: an amphipathic poly(L-lactide)-poly(ethylene glycol)-poly(L-lactide) triblock copolymer was coated with gelatin, then the microspheres were immersed in simulated body fluid containing dissolved alendronate. The resulting microspheres exhibited an increased effect on osteogenesis and bone regeneration compared with that of pristine microspheres lacking alendronate [42]. However, studies on HAp mineralization using self-assembled peptide templates could provide additional useful information, and applications based on peptide-template-HAp have rarely been reported.

Our main research is producing adsorbents for biosensing and bioseparation applications, that is, the materials need capable of adsorption selectively. Notably, we investigated not only the impact of calcium phosphate mineralization on peptide templates but also protein and enzyme adsorption performances by using as-synthesized materials [43-45]. It revealed that the morphology of the peptide-HAp hybrid materials included carboxyl groups was influenced from the secondary structures in peptides, and peptide-HAp composites with amino groups carried out for the application as glucose sensors because of its highly selective adsorption ability for proteins. In addition, we previously reported silica biomineralization on self-assembled peptide template using (leucine-lysine-leucine-leucine) ${ }_{5}-\mathrm{PEG}_{70}$ and (valine-lysine-valine-valine) ${ }_{5}-\mathrm{PEG}_{70}$ [46]. From these, we aimed at the preparation of selective protein adsorption agents using self-assembled peptide templates on HAp mineralization.

Hence, we prepared a peptide-poly(ethylene glycol) (peptide-PEG) block copolymer by solid-phase peptide synthesis using leucine $(\mathrm{L})$, glutamic acid $(\mathrm{E})$, and valine $(\mathrm{V})$ as rich carboxyl groups within peptide side chains (Ac-(LELL) 5 - PEG $_{70}$ and Ac-(VEVV) $5-P_{70} G_{70}$, Scheme 1). Subsequently, calcium phosphate mineralization using well-arranged peptide templates was attempted. The aim of this study is to provide insight into the influence of peptides on hybrid particle materials and the effect(s) of protein adsorption behavior on particles. 

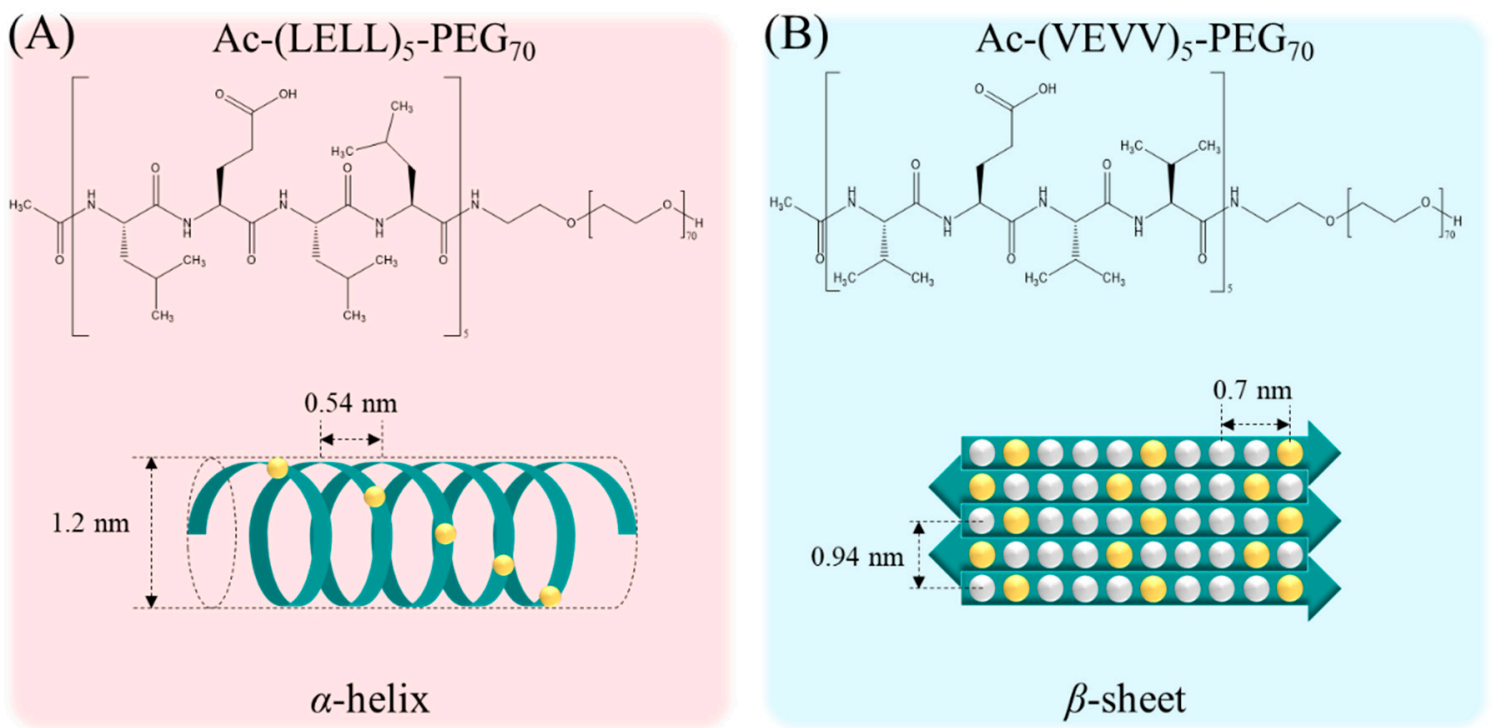

\section{$-\mathrm{COOH}$ group}

Scheme 1. Structural formula of the peptides. (A) Ac-(LELL) $5-\mathrm{PEG}_{70}$ and (B) Ac-(VEVV) $)_{5}-\mathrm{PEG}_{70}$ were self-assembled to $\alpha$-helix and $\beta$-sheet conformations, respectively.

\section{Results and Discussion}

\subsection{Peptide-HAp Characterization}

The circular dichroism (CD) spectra of Ac-(LELL) 5 - PEG $_{70}$ (abbreviated as LELL) and Ac-(VEVV) $)_{5}-\mathrm{PEG}_{70}(\mathrm{VEVV})$ are shown in Figure 1. Two negative peaks at 207 and $220 \mathrm{~nm}$ and a positive peak at $191 \mathrm{~nm}$ within LELL suggested $\alpha$-helixes. Conversely, the CD spectra of VEVV showed a positive peak at $195 \mathrm{~nm}$ and a negative peak at $215 \mathrm{~nm}$, indicating a $\beta$-sheet structure [47,48].

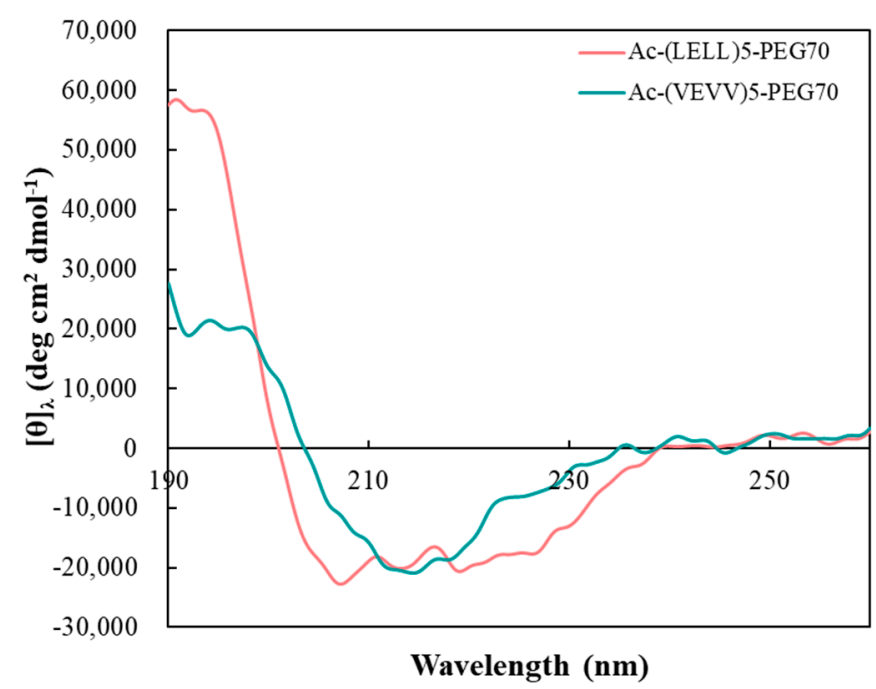

Figure 1. CD spectra of Ac-(LELL) $)_{5}-\mathrm{PEG}_{70}$ and Ac-(VEVV) $)_{5}-\mathrm{PEG}_{70}$. Each peptide was dissolved in $10 \mathrm{mM}$ phosphate buffer ( $\mathrm{pH} 7.0$ ) and the concentration of peptide was $1.0 \times 10^{-5} \mathrm{M}$.

Field-emission scanning electron microscopy (FE-SEM) and transmission electron microscopy (TEM) images of LELL-HAp ( 1 and $3 \mathrm{mg}$ ) and VEVV-HAp (1 and $3 \mathrm{mg}$ ) were observed as shown in Figure 2A,B. SEM images of peptide-HAp display nanorods with a length of approximately $60 \mathrm{~nm}$, similar to pristine HAp. Compared with LELL-HAp particles, the morphology of VEVV-HAp exhibited slightly larger plate like particles (Figure 2B). 


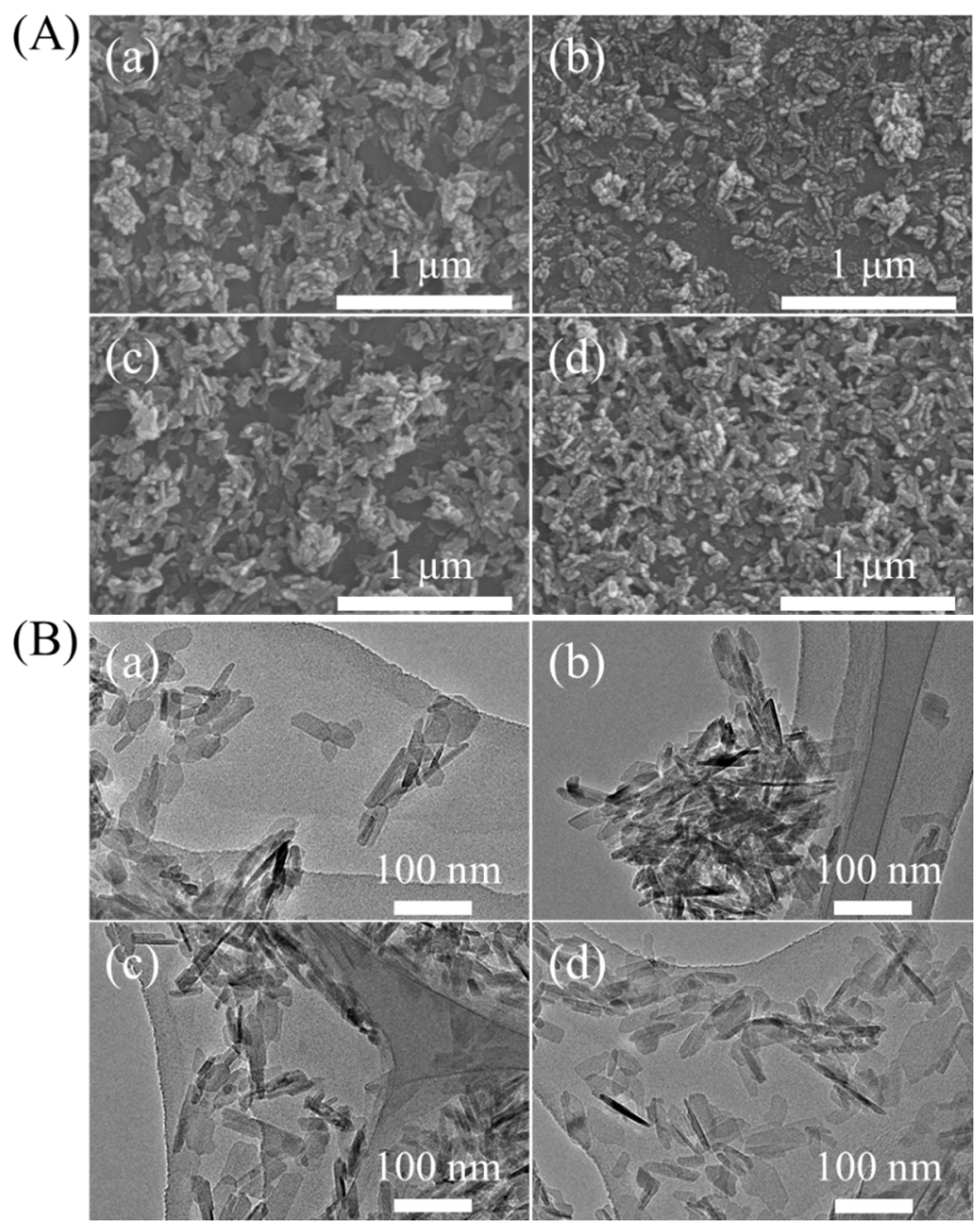

Figure 2. (A) FE-SEM and (B) TEM images of peptide-HAp composites: (a) LELL-HAp (1 mg), (b) LELL-HAp (3 mg), (c) VEVV-HAp (1 mg), and (d) VEVV-HAp (3 mg).

The Brunauer-Emmett-Teller (BET) surface area and pore volume and Barrett-Joyner-Halenda $(\mathrm{BJH})$ pore size distribution of peptide-HAp are shown in Figure 3A,B and Table 1; nitrogen adsorption-desorption isotherms could be classified as a type IV. The specific surface areas of LELL-HAp (1 and $3 \mathrm{mg}$ ) and VEVV-HAp (1 and $3 \mathrm{mg}$ ) were found to be 106, 101, 101, and $92 \mathrm{~m}^{2} \mathrm{~g}^{-1}$, whereas the pore volumes were $0.81,0.71,0.64$, and $0.62 \mathrm{~cm}^{3} \mathrm{~g}^{-1}$, respectively. In addition, pore sizes of $30 \mathrm{~nm}$ appeared in all samples. We previously observed that pore sizes of $70 \mathrm{~nm}$ were not present in any peptide-HAp besides bare HAp, and pore sizes of around $3 \mathrm{~nm}$ were confirmed in all samples. However, in the case of peptide-HAp, only $\alpha$-pLys-HAp (30 and $40 \mathrm{mg}$ ) have pore sizes of $30 \mathrm{~nm}$, of which pores may have impacted the enzyme stability of glucose oxidase immobilized on these materials [45]. As-prepared peptide-HAp is predicted to be usable for enzyme immobilization agents in biosensing and bioseparation.

The values of the $\mathrm{Ca} / \mathrm{P}$ molar ratios are listed in Table 1 . The Ca/P molar ratios of LELL-HAp ( 1 and $3 \mathrm{mg}$ ) and VEVV-HAp (1 and $3 \mathrm{mg}$ ) were 1.52, 1.50, 1.52, and 1.51, respectively. These ratios exhibited a relatively high degree of similarity to non-peptide-HAp, even though these values were lower than the stoichiometric ratio of HAp of 1.67. As a result, we observed that these calcium phosphates were low-crystallinity HAp or calcium-deficient HAp as composites of HAp and peptides. 
(A)

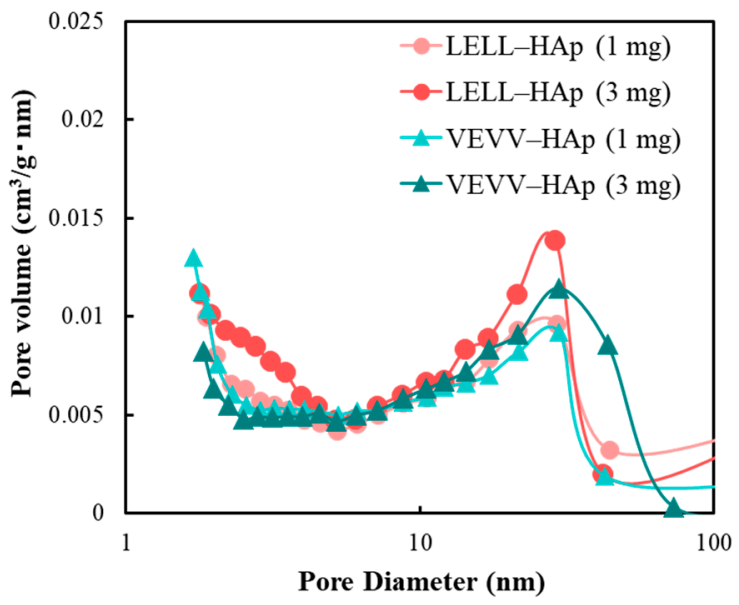

(B)

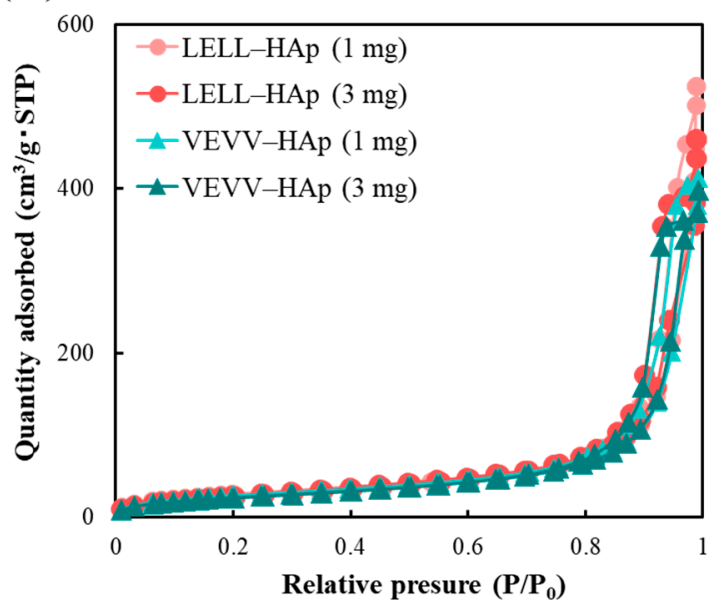

Figure 3. (A) Pore size distribution curves, and (B) nitrogen adsorption-desorption isotherms of LELL-HAp (1 and $3 \mathrm{mg}$ ) and VEVV-HAp (1 and $3 \mathrm{mg})$.

Table 1. Structural properties, $\mathrm{Ca} / \mathrm{P}$ molar ratio, amount of peptide, and zeta potential of peptide-HAp composites.

\begin{tabular}{|c|c|c|c|c|c|}
\hline Sample & $\begin{array}{l}\text { Surface Area } \\
\qquad\left(\mathrm{m}^{2} \mathrm{~g}^{-1}\right)\end{array}$ & $\begin{array}{l}\text { Pore Volume } \\
\qquad\left(\mathrm{cm}^{3} \mathrm{~g}^{-1}\right)\end{array}$ & $\begin{array}{c}\mathrm{Ca} / \mathrm{P} \\
\text { Molar Ratio }^{(b)}\end{array}$ & $\begin{array}{c}\text { Amount of Peptide (c) } \\
\text { (mg) }\end{array}$ & $\begin{array}{c}\text { Zeta Potential (d) } \\
(\mathrm{mV})\end{array}$ \\
\hline LELL-HAp (1 mg) & 106 & 0.81 & 1.52 & 0.43 & -19.8 \\
\hline LELL-HAp (3 mg) & 101 & 0.71 & 1.50 & 1.4 & -12.8 \\
\hline VEVV-HAp (1 mg) & 101 & 0.64 & 1.52 & 0.51 & -12.5 \\
\hline VEVV-HAp (3 mg) & 92 & 0.62 & 1.51 & 1.5 & -11.1 \\
\hline
\end{tabular}

(a) The specific surface area, pore volume, and pore size distribution of peptide-HAp were calculated on the basis of nitrogen adsorption-desorption isotherms by the Brunauer-Emmett-Teller (BET) and Barrett-Joyner-Halenda (BJH) methods. (b) To measure the $\mathrm{Ca} / \mathrm{P}$ molar ratio of peptide-HAp, inductively coupled plasma optical emission spectrometry (ICP-OES) was employed. (c) Peptide amounts within composites were determined by thermogravimetry and differential thermal analysis (TG-DTA). (d) The surface potential of peptide-HAp was measured via electrophoretic light scattering methods, whereas the particles were prepared by dispersion in $10 \mathrm{mM}$ phosphate buffer with pH 7.0 and sonication for $3 \mathrm{~min}$.

Figure 4A shows the powder X-ray diffraction (XRD) patterns of peptide-HAp. The diffraction peaks at $2 \theta=25.9^{\circ}, 31.8^{\circ}, 32.2^{\circ}, 32.8^{\circ}, 34.0^{\circ}, 39.7^{\circ}, 46.7^{\circ}, 49.5^{\circ}$, and $53.2^{\circ}$ correspond to the (002), (211), (112), (300), (202), (310), (222), (213), and (004) planes of hydroxyapatite, respectively, of which broad peaks indicate that all samples synthesized in this study were low-crystallinity HAp (JCPDS card no. 09-0432) [49].

Thermogravimetry and differential thermal analysis (TG-DTA) analysis was performed in order to confirm the peptide content in peptide-HAp composites, and peptide amounts are summarized in Table 1 , which were calculated by weight losses from $200{ }^{\circ} \mathrm{C}$ to $700{ }^{\circ} \mathrm{C}$ that were attributed to peptide loss. The relative peptide amounts of LELL-HAp ( 1 and $3 \mathrm{mg}$ ) and VEVV-HAp (1 and $3 \mathrm{mg}$ ) were $0.43,1.4,0.51$, and $1.5 \mathrm{mg}$, respectively. In other words, this reveals that the peptide amounts within peptide-HAp were $2.4,7.5,2.3$, and $6.5 \mathrm{wt} \%$ in the particles, respectively.

The zeta potential charge of peptide-HAp was also investigated, as shown in Table 1 . The surface potentials were $-19.8,-12.8,-12.5$, and $-11.1 \mathrm{mV}$ for LELL-HAp ( 1 and $3 \mathrm{mg}$ ) and VEVV-HAp ( 1 and $3 \mathrm{mg}$ ), respectively, leading to the independence of the amount of peptides.

Fourier transform infrared (FTIR) data of native peptide and peptide-HAp is shown in Figure 4B. The presence of $\mathrm{PO}_{4}{ }^{3-}$ functional groups in HAp can be observed by the bands at around 560, 600, 960, and $1020 \mathrm{~cm}^{-1}$ [49]. The $-\mathrm{C}=\mathrm{O}$ stretching vibration at $1600-1700 \mathrm{~cm}^{-1}$ for amide I could be assessed as the peptide structure. Among these, we focused on two main peaks at around 1650 and $1630 \mathrm{~cm}^{-1}$, attributed to $\alpha$-helix and $\beta$-sheet structure $[48,50]$. The LELL-HAp ( 1 and $3 \mathrm{mg}$ ) spectra had peaks corresponding to HAp; the $\mathrm{PO}_{4}{ }^{3-}$ bending vibration (O-P-O) at 560 and $600 \mathrm{~cm}^{-1}$ and the peaks at 
around 961 and $1024 \mathrm{~cm}^{-1}$ originated from bending modes of the $\mathrm{P}-\mathrm{O}$ bond in $\mathrm{PO}_{4}{ }^{3-}$. Moreover, the characteristic of an $\alpha$-helix in LELL from 1651 to $1653 \mathrm{~cm}^{-1}$ was observed. In the case of pure LELL, the band at $1652 \mathrm{~cm}^{-1}$ is attributed to an $\alpha$-helix structure. The characteristic peaks at around $560,600,961$, and $1022 \mathrm{~cm}^{-1}$ for VEVV-HAp ( 1 and $3 \mathrm{mg}$ ) could be designated as $\mathrm{PO}_{4}{ }^{3-}$ groups in HAp. Additionally, the bands registered at 1632 and $1634 \mathrm{~cm}^{-1}$ for VEVV-HAp ( 1 and $3 \mathrm{mg}$, respectively) were ascribed to $\beta$-sheet peaks. For VEVV, the same band ( $\beta$-sheet structure) was observed at $1626 \mathrm{~cm}^{-1}$. According to these results, the presence of both HAp and peptide in peptide-HAp could be confirmed; furthermore, the peaks derived from each peptide secondary structure were also classified.
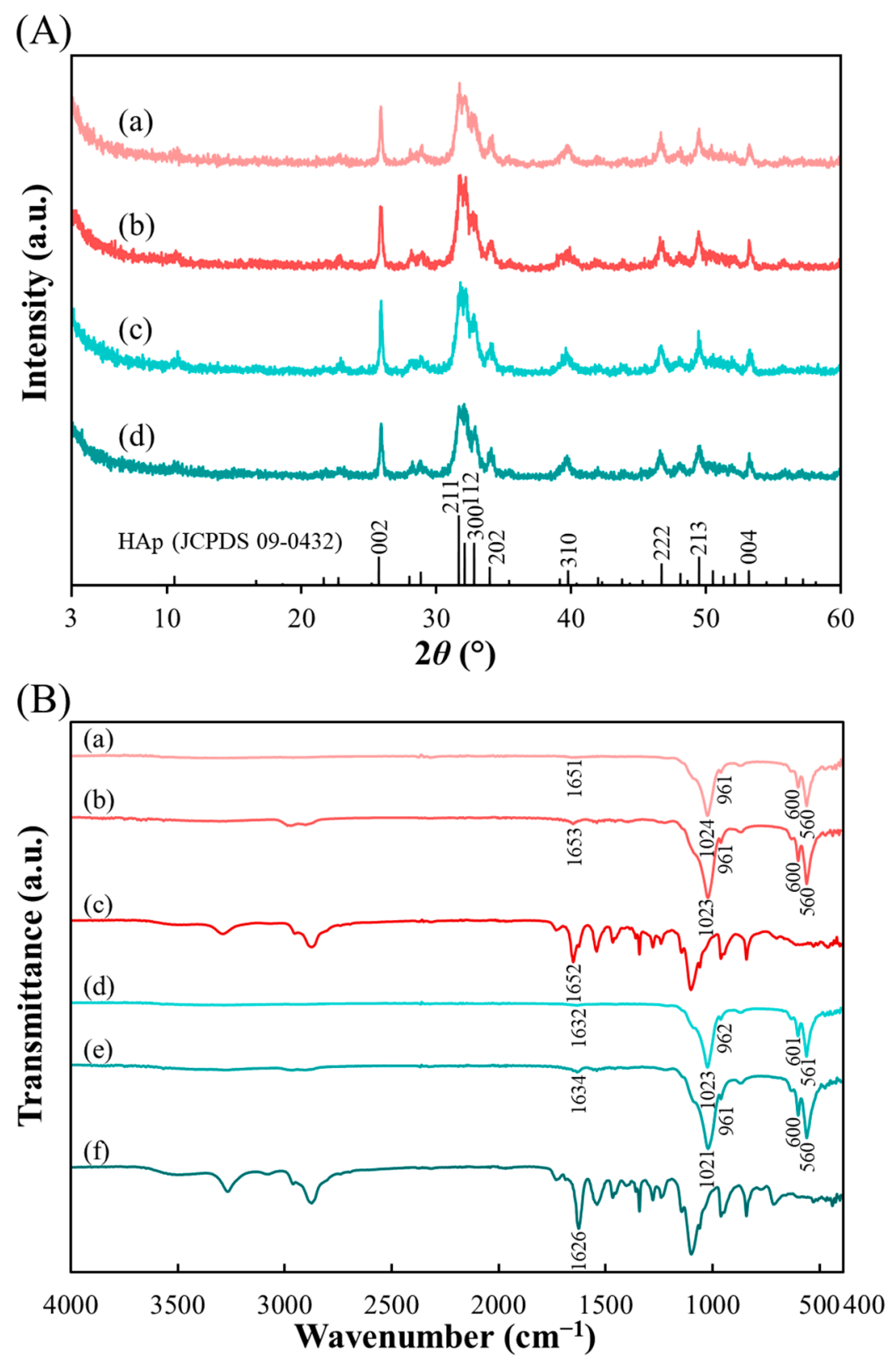

Figure 4. (A) X-ray diffraction patterns of (a) LELL-HAp (1 mg), (b) LELL-HAp (3 mg), (c) VEVV-HAp (1 mg), and (d) VEVV-HAp (3 mg) (JCPDS card no. 09-0432). (B) FTIR spectra of (a) LELL-HAp (1 mg), (b) LELL-HAp (3 mg), (c) pure Ac-(LELL) 5 -PEG 70 , (d) VEVV-HAp (1 mg), (e) VEVV-HAp (3 mg), and (f) pure Ac-(VEVV) $)_{5}-\mathrm{PEG}_{70}$.

Secondary structural contents of two peptides and that bound with Ca ions were clarified by FTIR analysis (Table 2). Firstly, native LELL and VEVV had higher contents of $\alpha$-helixes and $\beta$-sheets, 
respectively, as attributed to the CD data. Moreover, to investigate the secondary structure of peptide in peptide-HAp, we prepared each peptide bond with Ca ions as follows: $3 \mathrm{mg}$ LELL or VEVV was added to $20 \mathrm{~mL}$ of prepared $\left(\mathrm{CH}_{3} \mathrm{COO}\right)_{2}$ Ca solution $(15 \mathrm{mM})$. After stirring for $2 \mathrm{~h}$ at $20^{\circ} \mathrm{C}$, the solid materials were obtained via the freeze-drying process. Most secondary structures were of an $\alpha$-helix content for LELL bound with Ca ions; meanwhile, VEVV bound with Ca ions not only contained primarily $\beta$-sheet structures but also various secondary structural contents ( $\alpha$-helixes, $\beta$-turns, and others).

Table 2. Secondary structures (\%) of Ac-(LELL) $5-\mathrm{PEG}_{70}$ and Ac-(VEVV) 5 - $\mathrm{PEG}_{70}$.

\begin{tabular}{ccccc}
\hline Sample & $\alpha$-Helix & $\beta$-Sheet & $\beta$-Turn & Other \\
\hline LELL & $94 \%$ & $-*$ & $3 \%$ & $3 \%$ \\
LELL + Ca (a) & $>99 \%$ & $-^{*}$ & $-{ }^{*}$ & $-^{*}$ \\
VEVV & $-*$ & $96 \%$ & $1 \%$ & $3 \%$ \\
VEVV + Ca (a) & $2 \%$ & $47 \%$ & $24 \%$ & $27 \%$
\end{tabular}

* Trace percent. (a) Each peptide (Ac-(LELL) $5-\mathrm{PEG}_{70}$ and Ac-(VEVV) $\left.)_{5}-\mathrm{PEG}_{70}\right)(3 \mathrm{mg}$ ) was mixed with $20 \mathrm{~mL}$ $\left(\mathrm{CH}_{3} \mathrm{COO}\right)_{2} \mathrm{Ca}$ solution $(15 \mathrm{mM})$ and stirred for $2 \mathrm{~h}$ at $20^{\circ} \mathrm{C}$. The resulting product was then freeze-dried.

To investigate the elemental distribution in peptide-HAp particles, especially the peptide, scanning transmission electron microscopy (STEM) images, and energy-dispersive X-ray spectroscopy (EDX) maps were utilized (Figure 5A,B). Nitrogen is attributed to the peptides and calcium, and phosphorous corresponds to HAp. Nitrogen (yellow) is homogeneously distributed throughout nanoparticles; thus, it could be assumed that the peptides are distributed in the particles.

(A)

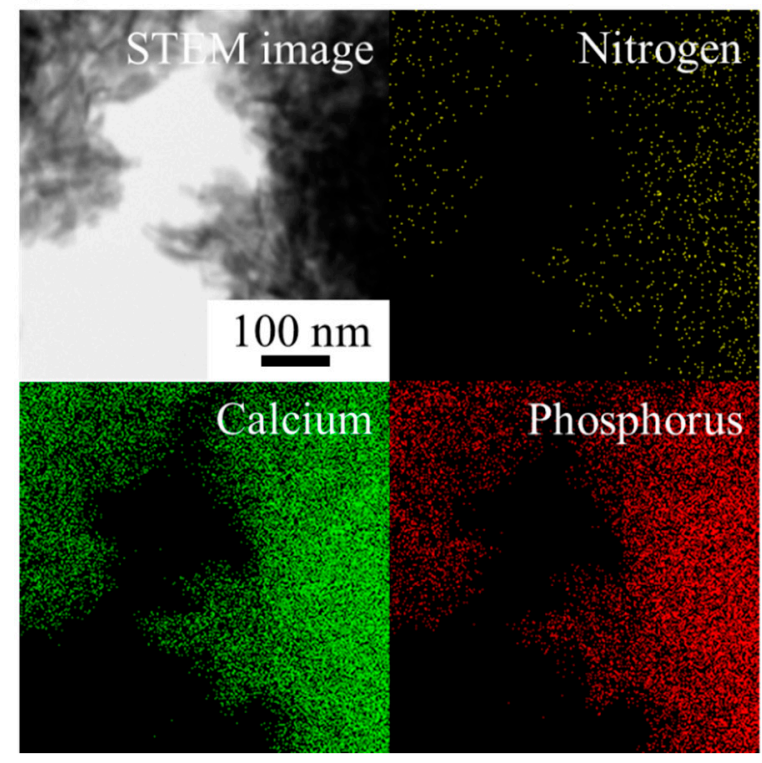

(B)

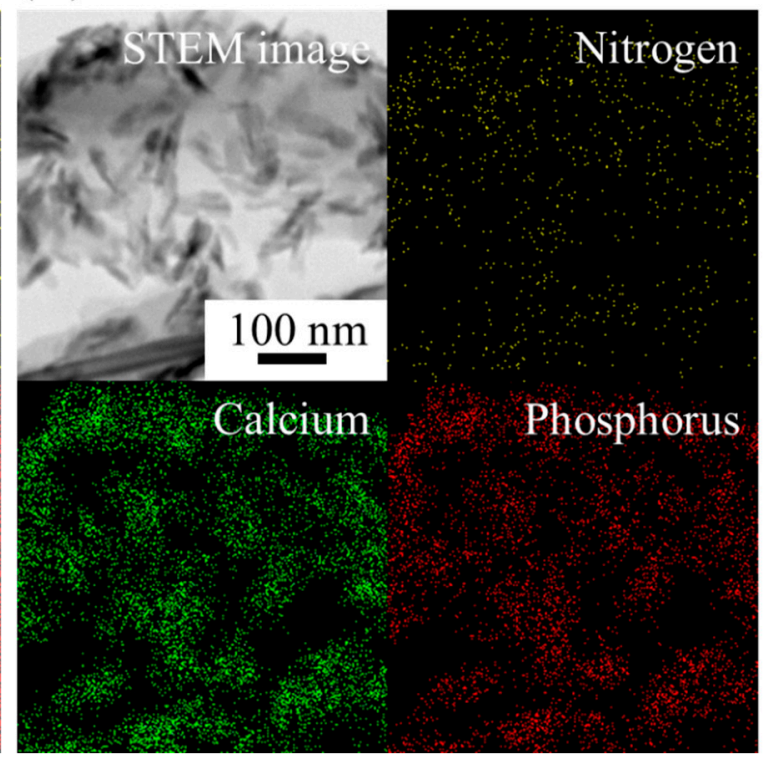

Figure 5. STEM images and EDX maps of elements of (A) LELL-HAp (3 mg) and (B) VEVV-HAp (3 mg). Nitrogen (yellow), calcium (green), and phosphorous (red) are displayed.

\subsection{Protein Adsorption on Peptide-HAp}

Three typical proteins with different isoelectric points (i.e., cytochrome c; Cyt c, myoglobin; MGB, and bovine serum albumin; BSA) were adsorbed not only on peptide-HAp but also non-peptide-HAp (Figure 6A). The capacity and tendency for protein adsorption on HAp were similar to the results obtained in a previous report [43]. The amounts of adsorbed Cyt c on LELL-HAp (1 mg) and VEVV-HAp (1 mg) were 94.8 and $78.3 \mu \mathrm{g} \mathrm{mg}^{-1}$, respectively. In addition, the adsorbed MGB amounts were 41.5 and $0.571 \mu \mathrm{g} \mathrm{mg}^{-1}$ for LELL-HAp (1 mg) and VEVV-HAp (1 mg), and the BSA capacities 
were 61.8 and $37.9 \mu \mathrm{g} \mathrm{mg}^{-1}$, respectively. In terms of the amounts of adsorbed Cyt c for LELL-HAp ( $3 \mathrm{mg}$ ) and VEVV-HAp (3 mg), the capacities were 30.4 and $64.8 \mu \mathrm{g} \mathrm{mg}^{-1}$, respectively, whereas two samples had either no or extremely low adsorption amounts for MGB and BSA. Furthermore, lysozyme (LSZ), conalbumin (ovotransferrin; OVT), and transferrin (TF) was adsorbed on peptide-HAp to confirm its selectivity only for basic protein (Figure 6B). The amounts of adsorbed LSZ on LELL-HAp (1 mg), VEVV-HAp (1 mg), LELL-HAp (3 mg), and VEVV-HAp (3 mg) were 41.9, 69.6, 96.4, and $115 \mu \mathrm{g} \mathrm{mg}{ }^{-1}$, respectively. For all peptide-HAp, adsorption amounts of OVT and TF were either no or extremely low. From these results, it could be hypothesized that selectivity for protein adsorption on peptide-HAp is due to the presence of glutamic acid (E) within the peptides. Moreover, VEVV-HAp exhibited a high blocking effect itself for the other proteins during the maintenance of Cyt $\mathrm{c}$ and LSZ adsorption capacities with increasing peptide amounts.

(A)

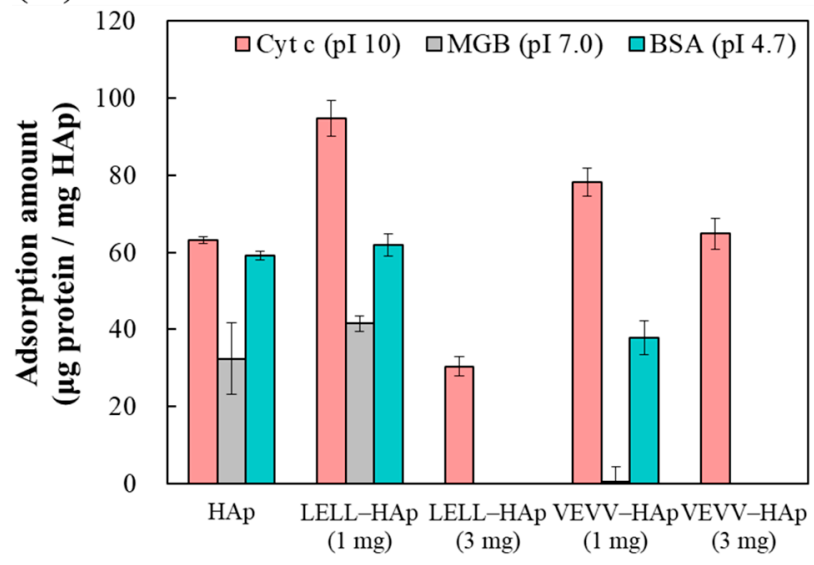

(B)

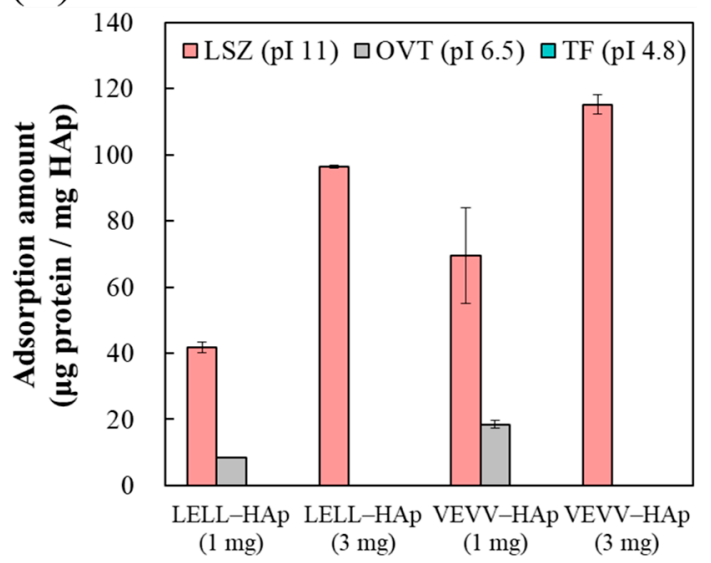

Figure 6. (A) Protein (cytochrome c, myoglobin, and bovine serum albumin) adsorption on HAp, LELL-HAp (1 and $3 \mathrm{mg}$ ), and VEVV-HAp (1 and $3 \mathrm{mg}$ ). (B) Protein (lysozyme, conalbumin, and transferrin) adsorption on LELL-HAp (1 and $3 \mathrm{mg}$ ) and VEVV-HAp (1 and $3 \mathrm{mg}$ ).

\subsection{Carboxyl Group Density in Peptide-HAp}

The determination of the carboxyl group density in peptide-HAp indicated the cause for selectivity of protein adsorption on peptide-HAp. The densities of carboxyl groups were 2.33, 3.38, 5.97, and $13.0 \mathrm{nmol} \mathrm{m}^{-2}$ for LELL-HAp (1 mg), VEVV-HAp (1 mg), LELL-HAp (3 mg), and VEVV-HAp (3 mg), respectively, in which the density of peptide-HAp was improved with increasing amounts of peptide. Moreover, the density of VEVV-HAp $(3 \mathrm{mg}$ ) was more than twofold higher compared with LELL-HAp ( $3 \mathrm{mg})$. From the results, the difference in Cyt c adsorption amounts between VEVV-HAp (3 mg) and LELL-HAp ( $3 \mathrm{mg}$ ) could be explained by the high carboxyl group density in VEVV-HAp ( $3 \mathrm{mg}$ ).

\section{Materials and Methods}

\subsection{Materials}

All chemicals were of analytical grade and were used as received without further purification. Calcium acetate monohydrate $\left[\left(\mathrm{CH}_{3} \mathrm{COO}\right)_{2} \mathrm{Ca} \cdot \mathrm{H}_{2} \mathrm{O}\right]$ and diammonium hydrogen phosphate $\left[\left(\mathrm{NH}_{4}\right)_{2} \mathrm{HPO}_{4}\right]$ were obtained from FUJIFILM Wako Pure Chemical Co. (Osaka, Japan). Cytochrome c from equine heart [Cyt c; isoelectric point $(\mathrm{pI})=10$, molecular weight $(\mathrm{Mw})=12,300 \mathrm{Da}$ ], myoglobin from equine skeletal muscle (MGB; $\mathrm{pI}=7.0, \mathrm{Mw}=17,800 \mathrm{Da}$ ), bovine serum albumin (BSA; pI = 4.7, $\mathrm{Mw}=67,000 \mathrm{Da})$, lysozyme from chicken egg white (LSZ; pI = 11, $\mathrm{Mw}=14,300 \mathrm{Da})$, conalbumin from chicken egg white $(\mathrm{OVT} ; \mathrm{pI}=6.5, \mathrm{Mw}=76,000 \mathrm{Da})$, and transferrin human (TF; $\mathrm{pI}=4.8, \mathrm{Mw}=80,000 \mathrm{Da}$ ) were purchased from Merck KGaA (Darmstadt, Germany). 1-Ethyl-3-(3-dimethylaminopropyl)carbodiimide hydrochloride (EDC; $\mathrm{Mw}=191.7$ ), 
$\mathrm{N}$-hydroxysuccinimide (NHS; $\mathrm{Mw}=115.1)$, and 5-aminofluorescein $(\mathrm{Mw}=347.3)$ were obtained from Tokyo Kasei Kogyo Co. (Tokyo, Japan). The Bio-Rad protein assay dye reagent concentrate was purchased from Bio-Rad Laboratories (Hercules, CA, USA).

\subsection{Preparation of Peptide-HAp Particles}

Two peptides (Ac-(LELL) $5-\mathrm{PEG}_{70}$ and Ac-(VEVV) 5 - $\left.\mathrm{PEG}_{70}\right)$ were prepared via solid-phase peptide synthesis according to our previous reports [30-33]. One or $3 \mathrm{mg}$ of Ac-(LELL) ${ }_{5}-\mathrm{PEG}_{70}$ or Ac-(VEVV) $)_{5}-\mathrm{PEG}_{70}$ was added to a $20 \mathrm{~mL}$ solution of dissolved $\left(\mathrm{CH}_{3} \mathrm{COO}\right)_{2} \mathrm{Ca}(52.8 \mathrm{mg})$, followed by stirring for $30 \mathrm{~min}$ at $20^{\circ} \mathrm{C}$. After addition of $20 \mathrm{~mL}\left(\mathrm{NH}_{4}\right)_{2} \mathrm{HPO}_{4}$ solution $(23.8 \mathrm{mg})$, the mixture was heated to $60^{\circ} \mathrm{C}$ at a heating rate of $1^{\circ} \mathrm{C} \mathrm{min}^{-1}$. The temperature was maintained for $3 \mathrm{~h}$ with stirring, and then the precipitant was collected by centrifugation at $6000 \mathrm{rpm}$ for $10 \mathrm{~min}$. The final products were washed twice with deionized water (Milli-Q, Merck KGaA, Darmstadt, Germany) and freeze-dried. To compare protein adsorption behavior, non-peptide-HAp was also synthesized using the same process as peptide-HAp.

\subsection{Characterization of Synthesized Peptide-HAp}

To analyze the secondary structure of Ac-(LELL) $)_{5}-\mathrm{PEG}_{70}$ and Ac-(VEVV) 5 - $\mathrm{PEG}_{70}$, the CD spectrum was measured using J-820 (JASCO Co., Tokyo, Japan) in a range scanning of 190-260 nm. The morphologies of all peptide-HAp samples were visualized with FE-SEM (S-4300, Hitachi Ltd., Tokyo, Japan) under $10.0 \mathrm{kV}$ accelerating voltage and TEM (JEM-2010, JEOL Ltd., Tokyo, Japan) at $200 \mathrm{kV}$ accelerator voltage. The specific surface area, pore volume, and pore size distribution were calculated on the basis of nitrogen adsorption-desorption isotherms using a TriStar 3000 (Shimadzu Co., Kyoto, Japan) via the BET and BJH models. For the measurement of the $\mathrm{Ca} / \mathrm{P}$ molar ratio of synthesized peptide-HAp, inductively coupled plasma optical emission spectrometry (ICP-OES; IRIS Advantage, Thermo Fisher Scientific Inc., Waltham, MA, USA) was employed. The calculated peptide amounts of peptide-HAp were analyzed by TG-DTA (Thermo Plus TG 8120, Rigaku Co., Tokyo, Japan) in the operation range of room temperature to $1000{ }^{\circ} \mathrm{C}$ (heating rate of $10{ }^{\circ} \mathrm{C} \mathrm{min}^{-1}$ ). ELSZ-1000 (Otsuka Electronics Co., Tokyo, Japan) was employed to measure the zeta potential of peptide-HAp, with the samples prepared via dispersion in $10 \mathrm{mM}$ phosphate buffer of $\mathrm{pH} 7.0$ with sonication for $3 \mathrm{~min}$. XRD (SmartLab SE/B1, Rigaku Co., Tokyo, Japan) analysis was carried out using $\mathrm{CuK} \alpha$ radiation operated at an accelerator voltage of $40 \mathrm{kV}$ and a beam intensity of $30 \mathrm{~mA}$. The XRD patterns were collected at a step size of $2.0^{\circ} \mathrm{min}^{-1}$ and a $2 \theta$ range between $3^{\circ}$ and $60^{\circ}$. FTIR spectra in the $400-4000 \mathrm{~cm}^{-1}$ range were recorded by FT/IR-4700 (JASCO Co., Tokyo, Japan) with attenuated total reflection. STEM (JEM-2100 Plus, JEOL Ltd., Tokyo, Japan) operated at $200 \mathrm{kV}$ with EDX (Noran System 7, Thermo Fisher Scientific Inc., Waltham, MA, USA) was used to analyze the element distribution of peptide over peptide-HAp.

\subsection{Protein Adsorption on Peptide-HAp}

Each protein (i.e., Cyt c, MGB, BSA, LSZ, OVT, and TF) was dissolved in $10 \mathrm{mM}$ phosphate buffer ( $\mathrm{pH}$ 7.0), and the protein solution was prepared at a concentration of $250 \mu \mathrm{g} \mathrm{mL} \mathrm{m}^{-1}$. Peptide-HAp (1.5 mg) was mixed with a $1 \mathrm{~mL}$ protein solution, followed by stirring overnight at $20^{\circ} \mathrm{C}$. The supernatant was separated from the mixture by centrifugation at 14,000 rpm for $5 \mathrm{~min}$, and excess protein in the supernatant was estimated using the Bradford method by UV-Vis spectroscopy (Infinite F200 PRO, Tecan Group Ltd., Männedorf, Switzerland) at $\lambda=595 \mathrm{~nm}$. Bio-Rad protein assay dye was employed for the evaluation of protein adsorption performance with the equation

$$
Q=Q_{0}\left(\frac{I_{0}-I}{I_{0}}\right)
$$


where $Q$ is the adsorption capacity of protein on peptide-HAp, $Q_{0}$ is the initial amount of protein, $I_{0}$ is the initial absorbance intensity in the supernatant, and $I$ is the absorbance intensity of the supernatant following adsorption.

\subsection{Calculation of Carboxyl Group Density in Peptide-HAp}

First, EDC (42.9 mg) and NHS (5.1 mg) were each dissolved in $3 \mathrm{~mL}$ of $10 \mathrm{mM}$ phosphate buffer ( $\mathrm{pH}$ 7.0), and the solutions $(500 \mu \mathrm{L}$ ) were mixed together. One mg of peptide-HAp was added to the mixture and stirred for $3 \mathrm{~h}$ at $20^{\circ} \mathrm{C}$. The solid materials were separated by centrifugation at 14,000 rpm for $5 \mathrm{~min}$ and then washed three times with $10 \mathrm{mM}$ phosphate buffer ( $\mathrm{pH}$ 7.0). The precipitant was resuspended in the same phosphate buffer $(500 \mu \mathrm{L})$, and then $500 \mu \mathrm{L}$ of 5 -aminofluorescein solution $\left(8 \mu \mathrm{g} \mathrm{mL}{ }^{-1}\right)$ was added to the suspension. After stirring in the dark overnight at $20^{\circ} \mathrm{C}$, the solid materials were collected by centrifugation at $14,000 \mathrm{rpm}$ for $5 \mathrm{~min}$ and washed with the aforementioned buffer. Finally, the carboxyl group density in the precipitant was redispersed in a $1 \mathrm{~mL}$ buffer and measured using a spectrofluorophotometer (RF-5300PC, Shimadzu Co., Kyoto, Japan), of which the excitation and emission wavelengths were 494 and $521 \mathrm{~nm}$, respectively.

\section{Conclusions}

In summary, we designed two types of self-assembling peptides with different secondary structures: (leucine-glutamic acid-leucine-leucine) ${ }_{5}-\mathrm{PEG}_{70}$ (LELL) and (valine-glutamic acid-valine-valine) ${ }_{5}$-PEG $_{70}$ (VEVV), and these peptides were used as templates for HAp biomineralization. Moreover, we also investigated the effect of secondary structures within peptide-template-HAp on the particles and protein adsorption behavior. It could be shown that as-synthesized peptide LELL or VEVV showed almost entirely $\alpha$-helix or $\beta$-sheet contents within secondary structures, respectively. The morphologies of all peptide-HAp were similar to bare HAp, whereas VEVV-HAp displayed a slightly plate-like structure. Additionally, all peptide-HAp have pore sizes of $30 \mathrm{~nm}$, which may be expected for enzyme stability on enzyme immobilization, as indicated in our previous study. Furthermore, for the adsorption properties of proteins, it was revealed that each peptide-HAp specifically adsorbed basic protein (i.e., Cyt c and LSZ). With increasing amounts of peptide, the blocking effects for proteins, except for basic protein, were also increased. Overall, the reason that VEVV-HAp $(3 \mathrm{mg})$ with $\beta$-sheet structures exhibited increased Cyt $\mathrm{c}$ adsorption amounts compared with LELL-HAp $(3 \mathrm{mg})$ containing $\alpha$-helix structures is explained as follows: the carboxyl group density at the surfaces of VEVV-HAp $(3 \mathrm{mg})$ was more than 2-times higher compared with LELL-HAp ( $3 \mathrm{mg}$ ) while the carboxyl group density of peptide-HAp incorporated $1 \mathrm{mg}$ of peptide amount was lower than that of peptide-HAp (3 mg). From these results, it can be stated that synthesized HAp on a self-assembling peptide template could be useful as a carrier for protein immobilization in biosensing and bioseparation applications and as enzyme-stabilizing agents.

Author Contributions: Conceptualization, K.K.; Data curation, S.K. and H.N.; Formal analysis, S.K. and H.N.; Writing - original draft preparation, S.K.; Writing—review and editing, S.L., F.N., and K.K.; Funding acquisition, S.L., F.N., and K.K.

Funding: The financial support of Grants-in-Aid for Scientific Research (C) no.15K06474 from the Japan Society for the Promotion of Science and A-STEP (JPMJTS1624) from the Japan Science and Technology Agency is gratefully acknowledged.

Acknowledgments: The author thanks Hiroyuki Iwata (Aichi Institute of Technology) for his help in the STEM-EDX observation. The authors would like to thank MARUZEN-YUSHODO Co., Ltd. (http://kw.maruzen. co.jp/kousei-honyaku/) for the English language editing.

Conflicts of Interest: The authors declare no conflict of interest. 


\section{Abbreviations}

$\begin{array}{ll}\text { HAp } & \text { Hydroxyapatite } \\ \text { PEG } & \text { Poly(ethylene glycol) } \\ \text { CD } & \text { Circular dichroism } \\ \text { FE-SEM } & \text { Field-emission scanning electron microscopy } \\ \text { TEM } & \text { Transmission electron microscopy } \\ \text { BET } & \text { Brunauer-Emmett-Teller } \\ \text { BJH } & \text { Barrett-Joyner-Halenda } \\ \text { XRD } & \text { Powder X-ray diffraction } \\ \text { TG-DTA } & \text { Thermogravimetry and differential thermal analysis } \\ \text { FTIR } & \text { Fourier transform infrared } \\ \text { STEM } & \text { Scanning transmission electron microscopy } \\ \text { EDX } & \text { Energy-dispersive X-ray spectroscopy } \\ \text { Cyt c } & \text { Cytochrome c } \\ \text { MGB } & \text { Myoglobin } \\ \text { BSA } & \text { Bovine serum albumin } \\ \text { LSZ } & \text { Lysozyme } \\ \text { OVT } & \text { Conalbumin } \\ \text { TF } & \text { Transferrin } \\ \text { EDC } & \text { 1-Ethyl-3-(3-dimethylaminopropyl)carbodiimide hydrochloride } \\ \text { NHS } & \text { N-Hydroxysuccinimide }\end{array}$

\section{References}

1. Jiang, W.; Yi, X.; McKee, M.D. Chiral biomineralized structures and their biomimetic synthesis. Mater. Horiz. 2019. [CrossRef]

2. Eichler-Volf, A.; Xue, L.; Dornberg, G.; Chen, H.; Kovalev, A.; Enke, D.; Wang, Y.; Gorb, E.V.; Gorb, S.N.; Steinhart, M. The influence of surface topography and surface chemistry on the anti-adhesive performance of nanoporous monoliths. ACS. Appl. Mater. Interfaces 2016, 8, 22593-22604. [CrossRef]

3. Cui, Y.; Li, D.; Bai, H. Bioinspired smart materials for directional liquid transport. Ind. Eng. Chem. Res. 2017, 56, 4887-4897. [CrossRef]

4. Liu, L.; Zhang, X.; Liu, X.; Liu, J.; Lu, G.; Kaplan, D.L.; Zhu, H.; Lu, Q. Biomineralization of stable and monodisperse vaterite microspheres using silk nanoparticles. ACS. Appl. Mater. Interfaces 2015, 7, 1735-1745. [CrossRef] [PubMed]

5. Wu, T.; Yang, Y.; Cao, Y.; Song, Y.; Xu, L.; Zhang, X.; Wang, S. Bioinspired DNA-inorganic hybrid nanoflowers combined with a personal glucose meter for onsite detection of miRNA. ACS. Appl. Mater. Interfaces 2018, 10, 42050-42057. [CrossRef] [PubMed]

6. He, M.; Zhang, Y.; Munyemana, J.C.; Wu, T.; Yang, Z.; Chen, H.; Qu, W.; Xiao, J. Tuning the hierarchical nanostructure of hematite mesocrystals via collagen-templated biomineralization. J. Mater. Chem. B 2017, 5, 1423-1429. [CrossRef]

7. Galloway, J.M.; Staniland, S.S. Protein and peptide biotemplated metal and metal oxide nanoparticles and their pattering onto surfaces. J. Mater. Chem. 2012, 22, 12423-12434. [CrossRef]

8. Chen, C.; Rosi, N.L. Peptide-based methods for the preparation of nanostructured inorganic materials. Angew. Chem. Int. Ed. 2010, 49, 1924-1942. [CrossRef]

9. Dickerson, M.B.; Sandhage, K.H.; Naik, R.R. Protein- and peptide-directed synthesis of inorganic materials. Chem. Rev. 2008, 108, 4935-4978. [CrossRef]

10. Sethi, M.; Pacardo, D.B.; Knecht, M.R. Biological surface effects of metallic nanomaterials for applications in assembly and catalysis. Langmuir 2010, 26, 15121-15134. [CrossRef]

11. Pan, L.; He, Q.; Liu, J.; Chen, Y.; Ma, M.; Zhang, L.; Shi, J. Nuclear-targeted drug delivery of TAT peptide-conjugated monodisperse mesoporous silica nanoparticles. J. Am. Chem. Soc. 2012, 134, 5722-5725. [CrossRef] 
12. Wada, N.; Horiuchi, N.; Nakamura, M.; Nozaki, K.; Nagai, A.; Yamashita, K. Controlled crystallization of calcium carbonate via cooperation of polyaspartic acid and polylysine under double-diffusion conditions in agar hydrogels. ACS Omega 2018, 3, 16681-16692. [CrossRef]

13. Wu, J.; Wang, Y.; Chen, C.; Chang, Y. Biomimetic synthesis of silica films directed by polypeptide brushes. Chem. Mater. 2008, 20, 6148-6156. [CrossRef]

14. Yao, Y.; Dong, W.; Zhu, S.; Yu, X.; Yan, D. Novel morphology of calcium carbonate controlled by poly(L-lysine). Langmuir 2009, 25, 13238-13243. [CrossRef] [PubMed]

15. Cai, C.; Lin, J.; Lu, Y.; Zhang, Q.; Wang, L. Polypeptide self-assemblies: Nanostructures and bioapplications. Chem. Soc. Rev. 2016, 45, 5985-6012. [CrossRef] [PubMed]

16. Ghatak, A.S.; Koch, M.; Guth, C.; Weiss, I.M. Peptide induced crystallization of calcium carbonate on wrinkle patterned substrate: Implications for chitin formation in Molluscs. Int. J. Mol. Sci. 2013, 14, 11842-11860. [CrossRef]

17. Bhandari, R.; Pacardo, D.B.; Bedford, N.M.; Naik, R.R.; Knecht, M.R. Structural control and catalytic reactivity of peptide-templated $\mathrm{Pd}$ and $\mathrm{Pt}$ nanomaterials for olefin hydrogenation. J. Phys. Chem. C 2013, 117, 18053-18062. [CrossRef]

18. Yuwono, V.M.; Hartgerink, J.D. Peptide amphiphile nanofibers template and catalyze silica nanotube formation. Langmuir 2007, 23, 5033-5038. [CrossRef]

19. Cui, Y.; Wang, Y.; Liu, R.; Sun, Z.; Wei, Y.; Zhao, Y.; Gao, X. Serial silver clusters biomineralized by one peptide. ACS Nano 2011, 5, 8684-8689. [CrossRef]

20. Yildirim, A.; Acar, H.; Erkal, T.S.; Bayindir, M.; Guler, M.O. Template-directed synthesis of silica nanotubes for explosive detection. ACS. Appl. Mater. Interfaces 2011, 3, 4159-4164. [CrossRef]

21. Acar, H.; Garifullin, R.; Guler, M.O. Self-assembled template-directed synthesis of one-dimensional silica and titania nanostructures. Langmuir 2011, 27, 1079-1084. [CrossRef] [PubMed]

22. Susapto, H.H.; Kudu, O.U.; Garifullin, R.; Yilmaz, E.; Guler, M.O. One-dimensional peptide nanostructure templated growth of iron phosphate nanostructures for lithium-ion battery cathodes. ACS. Appl. Mater. Interfaces 2016, 8, 17421-17427. [CrossRef] [PubMed]

23. Tomizaki, K.; Kubo, S.; Ahn, S.; Satake, M.; Imai, T. Biomimetic alignment of zinc oxide nanoparticles along a peptide nanofiber. Langmuir 2012, 28, 13459-13466. [CrossRef] [PubMed]

24. George, J.; Thomas, K.G. Surface plasmon coupled circular dichroism of Au nanoparticles on peptide nanotubes. J. Am. Chem. Soc. 2010, 132, 2502-2503. [CrossRef] [PubMed]

25. Lu, H.; Schäfer, A.; Lutz, H.; Roeters, S.J.; Lieberwirth, I.; Muñoz-Espí, R.; Hood, M.A.; Bonn, M.; Weidner, T. Peptide-controlled assembly of macroscopic calcium oxalate nanosheets. J. Phys. Chem. Lett. 2019, 10, 2170-2174. [CrossRef] [PubMed]

26. Tao, K.; Wang, J.; Li, Y.; Xia, D.; Shan, H.; Xu, H.; Lu, J.R. Short peptide-directed synthesis of one-dimensional platinum nanostructures with controllable morphologies. Sci. Rep. 2013, 3, 2565-2570. [CrossRef] [PubMed]

27. Wang, S.; Xue, J.; Zhao, Y.; Du, M.; Deng, L.; Xu, H.; Lu, J.R. Controlled silica deposition on self-assembled peptide nanostructures via varying molecular structures of short amphiphilic peptides. Soft Matter 2014, 10, 7623-7629. [CrossRef] [PubMed]

28. Wang, S.; Cai, Q.; Du, M.; Xue, J.; Xu, H. Synthesis of 1D silica nanostructures with controllable sizes based on short anionic peptide self-assembly. J. Phys. Chem. B 2015, 119, 12059-12065. [CrossRef]

29. Du, M.; Bu, Y.; Zhou, Y.; Zhao, Y.; Wang, S.; Xu, H. Peptide-templated synthesis of branched $\mathrm{MnO}_{2}$ nanowires with improved electrochemical performances. RSC Adv. 2017, 7, 12711-12718. [CrossRef]

30. Nonoyama, T.; Kinoshita, T.; Higuchi, M.; Nagata, K.; Tanaka, M.; Sato, K.; Kato, K. Multistep growth mechanism of calcium phosphate in the earliest stage of morphology-controlled biomineralization. Langmuir 2011, 27, 7077-7083. [CrossRef]

31. Kuno, T.; Nonoyama, T.; Hirao, K.; Kato, K. Influence of the charge relay effect on the silanol condensation reaction as a model for silica biomineralization. Langmuir 2011, 27, 13154-13158. [CrossRef] [PubMed]

32. Nonoyama, T.; Kinoshita, T.; Higuchi, M.; Nagata, K.; Tanaka, M.; Sato, K.; Kato, K. TiO 2 synthesis inspired by biomineralization: Control of morphology, crystal phase, and light-use efficiency in a single process. J. Am. Chem. Soc. 2012, 134, 8841-8847. [CrossRef] [PubMed]

33. Murai, K.; Higuchi, M.; Kinoshita, T.; Nagata, K.; Kato, K. Calcium carbonate biomineralization utilizing a multifunctional $\beta$-sheet peptide template. Chem. Commun. 2013, 49, 9947-9949. [CrossRef] [PubMed] 
34. Morejón, L.; Delgado, J.A.; Ribeiro, A.A.; Oliveira, M.V.; Mendizábal, E.; García, I.; Alfonso, A.; Poh, P.; Griensven, M.; Balmayor, E.R. Development, characterization and in vitro biological properties of scaffolds fabricated from calcium phosphate nanoparticles. Int. J. Mol. Sci. 2019, 20, 1790. [CrossRef] [PubMed]

35. Guan, J.; Yang, J.; Dai, J.; Qin, Y.; Wang, Y.; Guo, Y.; Ke, Q.; Zhang, C. Bioinspired nanostructured hydroxyapatite/collagen three-dimensional porous scaffolds for bone tissue engineering. RSC Adv. 2015, 5, 36175-36184. [CrossRef]

36. Cai, Y.; Li, H.; Karlsson, M.; Leifer, K.; Engqvist, H.; Xia, W. Biomineralization on single crystalline rutile: The modulated growth of hydroxyapatite by fibronectin in a simulated body fluid. RSC Adv. 2016, 6, 35507-35516. [CrossRef]

37. Zhang, Y.; Li, K.; Zhang, Q.; Liu, W.; Liu, Y.; Banks, C.E. Multi-dimensional hydroxyapatite (HAp) nanocluster architectures fabricated via nafion-assisted biomineralization. New J. Chem. 2015, 39, 750-754. [CrossRef]

38. Yang, Y.; Cui, Q.; Sahai, N. How does bone sialoprotein promote the nucleation of hydroxyapatite? A molecular dynamics study using model peptides of different conformations. Langmuir 2010, 26, 9848-9859. [CrossRef] [PubMed]

39. Weiger, M.C.; Park, J.J.; Roy, M.D.; Stafford, C.M.; Karim, A.; Becker, M.L. Quantification of the binding affinity of a specific hydroxyapatite binding peptide. Biomaterials 2010, 31, 2955-2963. [CrossRef] [PubMed]

40. Mukherjee, K.; Ruan, Q.; Nutt, S.; Tao, J.; Yoreo, J.J.D.; Moradian-Oldak, J. Peptide-based bioinspired approach to regrowing multilayered aprismatic enamel. ACS Omega 2018, 3, 2546-2557. [CrossRef]

41. Hadagalli, K.; Panda, A.K.; Mandal, S.; Basu, B. Faster biomineralization and tailored mechanical properties of marine-resource-derived hydroxyapatite scaffolds with tunable interconnected porous architecture. ACS Appl. Bio Mater. 2019, 2, 2171-2184. [CrossRef]

42. Wei, P.; Yuan, Z.; Jing, W.; Huang, Y.; Cai, Q.; Guan, B.; Liu, Z.; Zhang, X.; Mao, J.; Chen, D.; et al. Strengthening the potential of biomineralized microspheres in enhancing osteogenesis via incorporating alendronate. Chem. Eng. J. 2019, 368, 577-588. [CrossRef]

43. Kojima, S.; Nagata, F.; Kugimiya, S.; Kato, K. Synthesis of peptide-containing calcium phosphate nanoparticles exhibiting highly selective adsorption of various proteins. Appl. Surf. Sci. 2018, 458, 438-445. [CrossRef]

44. Kojima, S.; Nagata, F.; Inagaki, M.; Kugimiya, S.; Kato, K. Avidin-adsorbed peptide-calcium phosphate composites exhibiting high biotin-binding activity. New J. Chem. 2019, 43, 427-435. [CrossRef]

45. Kojima, S.; Nagata, F.; Inagaki, M.; Kugimiya, S.; Kato, K. Enzyme immobilisation on poly-L-lysine-containing calcium phosphate particles for highly sensitive glucose detection. RSC Adv. 2019, 9, 10832-10841. [CrossRef]

46. Kuno, T.; Nonoyama, T.; Hirao, K.; Kato, K. Structural formation ability of peptide secondary structure on silica biomineralization. Chem. Lett. 2012, 41, 1547-1549. [CrossRef]

47. Qin, S.; Jiang, H.; Peng, M.; Lei, Q.; Zhuo, R.; Zhang, X. Adjustable nanofibers self-assembled from an irregular conformational peptide amphiphile. Polym. Chem. 2015, 6, 519-524. [CrossRef]

48. Fry, H.C.; Silveira, G.Q.; Cohn, H.M.; Lee, B. Diverse bilayer morphologies achieved via $\alpha$-helix-to- $\beta$-sheet transitions in a short amphiphilic peptide. Langmuir 2019, 35, 8961-8967. [CrossRef]

49. Stevanović, M.; Đošić, M.; Janković, A.; Kojić, V.; Vukašinović-Sekulić, M.; Stojanović, J.; Odović, J.; Sakač, M.C.; Rhee, K.Y.; Mišković-Stanković, V. Gentamicin-loaded bioactive hydroxyapatite/chitosan composite coating electrodeposited on titanium. ACS Biomater. Sci. Eng. 2018, 4, 3994-4007. [CrossRef]

50. Suades, A.; Alcaraz, A.; Cruz, E.; Álvarez-Marimon, E.; Whitelegge, J.P.; Manyosa, J.; Cladera, J.; Perálvarez-Marín, A. Structural biology workflow for the expression and characterization of functional human sodium glucose transporter type 1 in Pichia pastoris. Sci. Rep. 2019, 9, 1203-1213. [CrossRef]

(C) 2019 by the authors. Licensee MDPI, Basel, Switzerland. This article is an open access article distributed under the terms and conditions of the Creative Commons Attribution (CC BY) license (http://creativecommons.org/licenses/by/4.0/). 